\title{
Determinants of Self-Employment Intentions among Students in Tanzania Higher Learning Institutions
}

\author{
Kelvin M. Mwita \\ Assistant Lecturer, School of Public Administration and Management, \\ Mzumbe University, Mzumbe, Tanzania \\ E-Mail: kmwita@mzumbe.ac.tz
}

\begin{abstract}
This study aimed at examining determinants of selfemployment intentions among students in Tanzania higher learning institutions. The study was guided by the theory of planned behavior which postulates that an intention is influenced by the attitude toward behavior, the subjective norms of the behavior, and the individual's control of the behavior. The study used Mzumbe University as a case study from which 400 respondents were drawn by using a simple random sampling technique. A standard questionnaire was used to collect data and a study attained a response rate of 82\%. Data analysis involved multiple linear regression analysis. The study found that gender $(\beta=-.028, p=.751)$ and academic performance $(\beta=.016, p=.671)$ had no significant relationship with self-employment intentions of students while entrepreneurship education $(\beta=.303, p=.000)$ and having parents who are self-employed $(\beta=.211, p=.031)$ had significant relationship with self-employment intentions. The study recommends higher learning institutions to have curriculums that help students to acquire entrepreneurship education sufficiently. Moreover, students are advised to have personal initiatives in looking for entrepreneurship knowledge and skills. Parents are also recommended to establish businesses as their main or alternative sources of income in order to influence entrepreneurial tendencies in the current and coming generations as a solution towards unemployment problem.

Keywords: Self-Employment Intentions, Self-Employment Intentions, Entrepreneurship, Graduate Employability, Entrepreneurship Education, Tanzania
\end{abstract}

\section{INTRODUCTION}

From the time immemorial, the problem of unemployment has always been drawing attention of different stakeholders in both developed and developing economies, giving the devastating effect of this phenomenon on individuals, the society, and the economy at large (Popoola \& Ajayi, 2016). In the developing world, employment problem is seen not to be in high unemployment rather in underemployment which is within self-employment and casual wage employment (Ghose, Majid \& Ernst, 2008; Poschke, 2018).

Youth unemployment is one of major global challenges. The youth are less likely to get employed comparing to the adults. The global unemployment rate for young people is $13 \%$ while their counterparts' rate is $4.3 \%$ (ILO, 2018). Globally, graduates from higher learning institutions are still facing the same problem regardless of amount of time and money they have spent in acquiring education (Hwang, 2017). In response, various stakeholders have come up with more active labor market interventions to deal with the problem of youth unemployment (Burchell \& Coutts, 2018).

Recognizing that unemployment level of young graduates is huge and entrepreneurship of young graduates can be one of ways in dealing with this problem, the role of educational institutions is considered to be very important in developing an entrepreneurial attitude (Silva\& Nobre, 2018). Entrepreneurs are considered the backbone of the industries as they come up with innovative business ideas which ultimately contribute to the social and economic growth (Isral \& Saleem, 2018). People who have entrepreneurial intention are more likely to start a business in the future than those who have lower or lack of entrepreneurial intentions. (Al-Harrasi, Al-Zadjali \& Al-Salti (2014). This implies that understanding entrepreneurial intentions is one of important aspects to be studied.

A. Statement of the Problem: In Tanzania, youth unemployment is estimated at $9.4 \%$. This is due to insufficient formal job creating which causes restless, frustration and social insecurity among the youth since formal sector in Tanzania does not create many new job opportunities (ILO, 2018). Moreover, each year about 900,000 young Tanzanians enter the labour market that is generating only 50,000 to 60, 000 jobs (The Citizen, 2017). This means new jobs cannot accommodate Tanzanians produced by higher learning institutions something that calls for self employment as one of the remedies to graduate unemployment.

It is insisted that Higher Education Institutions (HEI) as social transformers should provide an environment conducive to their students getting involved in processes of creation of new companies (Velásquez et al., 2017). The literature informs us that entrepreneurship is a function of Self-employment intentions (Torres et al., 2017).

A number of studies such as Katundu \& Gabagambi (2014); Mwasalwiba, Dahles and Wakkee (2012) have offered numerous reasons to why Tanzania higher learning institutions graduates do not opt for self-employment after graduation. However, there are limited empirical evidences to show what determine Self-employment intentions of higher learning students (before entering the labour market) something that this study is expecting to address. 
B. Research Purpose: The study aimed at establishing the determinants of self-employment intentions among students in Tanzania higher learning institutions. Four determinants were studied which included gender, entrepreneurship education, academic performance and parents' selfemployment history.

C. Hypotheses: The study tested four null hypotheses

$H_{O} 1$ : There is no statistically significant association between gender and self-employment intentions among students in Tanzania Higher learning institutions

$H_{O}$ 2: There is no statistically significant association between entrepreneurship education and self-employment intentions among students in Tanzania Higher learning institutions

$H_{O}$ : There is no statistically significant association between students' academic performance and their selfemployment intentions in Tanzania Higher learning institutions

$H_{O} 4$ : There is no statistically significant association between parents' self-employment history rand selfemployment intentions among students in Tanzania Higher learning institutions

\section{LITERATURE REVIEW}

\section{A. Definition of Key Concepts}

1. Entrepreneurship: Cadar and Badulescu (2015) define entrepreneurship to imply an ability to initiate, innovate, take decisions, and being responsible enough to take risks of undertaking economic activities by an individual who possesses a certain capital. Hessels and Naude (2017) provide a broader definition which explains entrepreneurship as the resource, process and state of being through which individuals with ability and agency utilize positive opportunities in the market for generating individual and/or social value. Havinal (2009) defines entrepreneurship by associating it with what an entrepreneur does; entrepreneurship involves creation of something new, organizing production and undertaking risks and handling economic uncertainty involved in enterprise. This implies that entrepreneurship is directly linked to creation of a startup. In words of Greco and Jong (2017) start-ups represent an important cluster of the entrepreneurship literature mainly for their widely recognized potential to innovate, contraposing them to large organizations.

2. Entrepreneurial Intentions (EI): EI is a "selfacknowledged conviction" by any person that he/she is willing to initiate new business enterprise, and he/she continuously plans to accomplish this in future (Farrukh, Alzubi, Shahzad, \& Kanwal, 2018). A similar definition was offered by Thompson (2009) who defined EI as a conscious awareness and conviction by a person that set up a new business venture and plans to do so in the future. As a general rule, the stronger an individual's intention to undertake a specific behaviour, the more likely that individual would engage in that behavior (Mwiya, Wang,
Kaulung'ombe, \& Kayekesi, 2018). In business perspective, this view is supported by Johnmark and Munene (2016) who observed that the intention is a contributing factor in initiating venture formation and has substantial impact on the success of business.

\section{THEORY OF PLANNED BEHAVIOUR (TPB)}

TPB was delivered by Ajzen (1991) from the Theory of Reasoned Action (TRA) that was originally proposed by Fishbein and Ajzen (1975). TRA suggests that the conception of behavioral intention implies how attitude and behavior relates and set forth the concept of as a subsequent predictor of intention. In the theory, attitude means an individual's overall assessment of carrying out the behavior, subjective norm refers to perceived social pressure from significant others to perform, or not perform a behavior (Williams, He \& Conners, 2018). TPB is a socialpsychological theory that explains behavioral decisionmaking processes of human beings with aiming at understanding and predicting the behavior of individuals, advocating that the successful completion of human behaviors are mainly controlled by individual will (Zhang, 2018). According to the theory intention is itself influenced by the attitude toward a particular behavior, the subjective norms of the behavior, and the individual's control of the behavior (Asadollahi, Miri, Norozi, Hosseini \& Sharifzade, 2017).

TPB considers attitude, subjective norms, and perceived behavioral control as determinants of intention perceived behavioral control is an antecedent of behavior as well as an antecedent of intention. Attitude encompasses an individual's evaluation of the benefits of engaging in a particular behavior. Subjective norms are the opinions of an individual's significant others relative to the behavior under consideration. Perceived behavioral control addresses an individual's perception of being able to accomplish the contemplated behavior (Leavell, 2017)

In this study, TPB would imply that students who have a positive attitude toward entrepreneurship, who perceive support from their surroundings (subjective norm), and who believe in their own ability to undertake entrepreneurial activities (perceived behavioral control) should have stronger Self-employment intentions.

\section{EMPIRICAL REVIEW}

A. Gender and Self-Employment Intentions: The study of Indarti and Kristiansen (2003) sought to identify determinants of Self-employment intentions among young people using Norwegian students. Gender was one of other independent variables that the study attempted to establish its relationship with Self-employment intention. The study found that gender had no statistically significant impact on Self-employment intention. These findings are contrary to those of Jinying and Pelagie (2014), in their study they sought to find out the determinants of Self-employment 
intention among African students studying various disciplines in China base on the theory of planned behavior. From a sample of 148 students it was found that gender is one of the determinants of self employment intentions. These findings are consistent with those of Nguyen (2018) that found that male business students display higher Selfemployment intention than female business students.

The study of Ojeyumi, Oyekele, Agberotimi, and Odedayo (2018) examined the influence of gender and self-efficacy on Self-employment intention among Obafemi Awolowo University undergraduates in Ile-Ife, Nigeria. A descriptive survey design was used in conducting the study. One hundred and forty (140) students comprising 74 males and 66 females whose ages ranged between 16 and 35 years participated in the study. Participants responded to items of a structured questionnaire, the response which was subjected to statistical analysis. The results showed there was no significant difference between male and female students on entrepreneurship intention $(\mathrm{t}(138)=1.81$, $\mathrm{p}$ $>.05)$.

B. Entrepreneurship Education and Self-Employment Intentions: The study of Faloye and Olatunji (2018) examined the main determinants of entrepreneurship intentions and the link between entrepreneurship attitude orientations and business ownership intentions among Nigeria's fresh graduates. Survey designed was used and through questionnaires data were collected from 230 randomly selected respondents from Ondo State. The study found that entrepreneurship education significantly affect an intention of fresh graduates to start a business $(r=0.313$; $\rho$ $=0.000$ ). The study of Hattab (2014) studied the impact of entrepreneurship education on the Self-employment intentions of university students. The findings suggested a positive association between entrepreneurship education and intentions and perceived desirability.

The study of Tarus, Kemboi, Okemwa and Otiso (2016) examined the determinants of Self-employment intention in Kenya using selected Kenyan Universities. Among other objectives the study sought to establish the relationship between entrepreneurship and Self-employment intention. The study was guided by Ajzen's Theory of Planned Behavior. Explanatory research design was adopted with a target of 1,649 undergraduate business students from Moi, Mount Kenya and Catholic universities in Uasin Gishu County. A sample size of 321 respondents was obtained. The study found that education had significant and positively correlated with Self-employment intention $(\mathrm{r}=0.564)$.

The study of Nyello, Kalufya, Rengua, Nsolezi and Ngirwa (2015) studied the effect of Entrepreneurship Education on the Entrepreneurial Behaviour. The study used graduates in the Higher Learning Institutions in Tanzania. A questionnaire as a data collection tool was used to collect data from 233 students of the Institute of Social Work graduates. The results indicated the positive effect of entrepreneurship education on entrepreneurial behavior.

C. Academic Performance and Self-Employment Intentions: Archarja (2017) among other factors explored the effect of academic performance of undergraduate students under Royal University of Bhutan on their Self-employment intention. Data were collected from 384 respondents who were sampled using Yamane Formula. The study conducted a chi-square test of independence to examine individual factors on their Self-employment intentions. The study showed no relationship between academic performance and their Self-employment intentions after graduation. Similar findings were found by Osakede, Lawanson and Sobowale (2017). Their study was done in Nigeria to find the relationship between Self-employment interest and academic performance by using 250 undergraduate students of Ibadan University. The found no relationship between Self-employment interest and academic performance.

The study of Bhassegem (2016) showed a weak relationship $\left(\mathrm{R}^{2}=0.042\right)$ between academic performance which was measured using grade point and Self-employment intention. The study used a sample of 1007 obtained from 4 different countries, namely Canada, Belgium, France and Algeria

D. Parents' Self-Employment History and Self-Employment Intentions: The study of Megibaru (2014) examined sociodemographic determinants for Self-employment intention of University Students using the Case of University of Gondar graduating students. The study used cross-sectional survey through a mixed research design. A sample of 310 respondents was involved and it was found that about 56\% of graduating students were not entrepreneurially intended. Parents' self employment was found to be one of significant predictors of Self-employment intention. The findings are consistent with those of Kumar and Prabhu (2017) who investigated parental factors and entrepreneurial attitude. It was found that the Self-employment intent is influenced by the parents; a higher degree of the influence for a male child being from a family with both parents pursuing selfemployment and a lower degree for the female child with self- employed parent.

Similarly, the study of Fatoki (2014) which was done in South African University from the final year students (undergraduate level) in the Department of Business Management indicate that students whose parents are involved in business have a higher level of Selfemployment intention compared to students whose parents are not involved in business.

However, the difference was not statistically significant. The findings are also supported by those of Ahmed et al., (2010) who studied determinants of students' entrepreneurial career intentions using evidence from business graduates in Pakistan. The study found that family exposure to business and level of exposure inclines students to become entrepreneur. 
However, Rachmawan, Lizar and Mangundjaya (2015) who conducted in Indonesia from 215 new under graduate students found that parent's influence has no significant association with Self-employment intention.

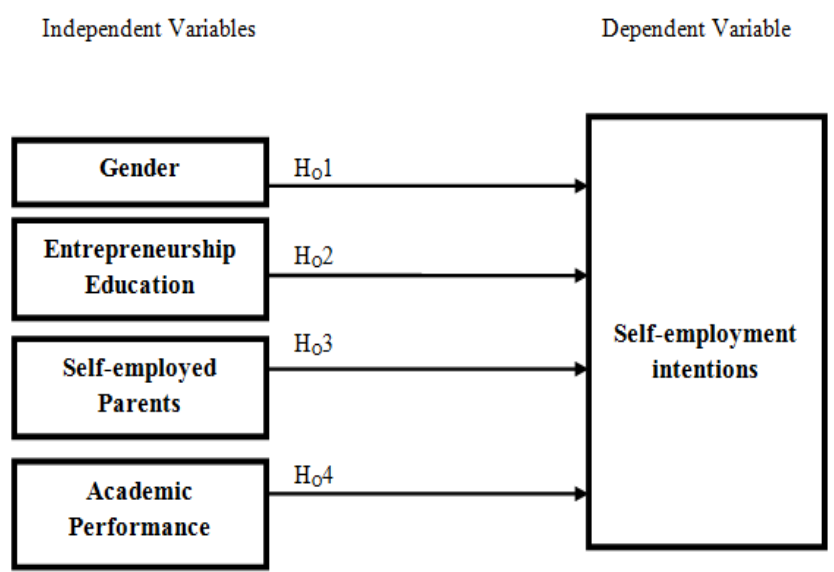

Fig. 1 Conceptual Framework

\section{RESEARCH METHODS}

A case study method was used. Case study enables a researcher to closely examine the data within a specific context. In most cases, in a case study a researcher selects a small geographical area or a very limited number of individuals as the subjects of study (Zainal, 2007). Mzumbe University was used as a case study. Mzumbe University was accredited to be a fully fledged University in 2001 but her history as a learning institution can be traced back to 1953 and therefore it has more than 60 years of training provision.

The study used a simple random sampling technique to sample respondents from a sample frame of 2,067 final year students that included undergraduate and postgraduate students. A list of final year students was obtained from the University Admission Officer. Yamane's formula was used to calculate a sample of 400 respondents.

Primary data was collected by using standard questionnaires with closed questions. In closed questions the possible answers are set out in the questionnaire and the respondents tick the category that best describes the respondent's answer (Kumar, 2011). The tool enabled a researcher to save time and other resources specifically money since data collection involved a relatively large number of respondents.

Out of 400 respondents who were given questionnaires 344 returned them which accounted for a response rate of $86 \%$. According to Mugenda and Mugenda (2012) a response rate of $50 \%$ is adequate for analysis and reporting, a rate of $60 \%$ is generally good while a response rate of above $70 \%$ is excellent. This is consistent with the recommendation of Kothari (2011) who opines that a response rate of above $70 \%$ is deemed to be very good. This implies that $86 \%$ response rate that this study attained is sufficient for data analysis and reporting.

\section{DATA ANALYSIS}

With an assistance of the $20^{\text {th }}$ version of IBM software SPSS, inferential statistics was employed in data analysis. Inferential statistics builds on probability theory to test hypotheses formally, permit inferences from a sample to a population, and test whether descriptive results are likely to be due to random factors or to a real relationship (Neuman, 2014). Regression analysis was used. Regression analysis helped in designing a model for predicting the unit change of one variable (determinant) on the other (Self-employment intention).

\section{FINDINGS AND DISCUSSION}

A. Reliability of Data Collection Tool: In order to ensure that the questionnaire used for data collection was well understood by the respondents 40 students who are $10 \%$ of the parent sample size were used for a pilot study aiming at improving the questionnaire for actual data collection. According to Connelly (2008) extant literature suggests that a pilot study sample should be $10 \%$ of the sample size planned for the final study hence 40 students was sufficient for piloting. The pilot study helped to improve some questions that were not well understood by the respondents. Further, two (2) research experts were given the questionnaires to suggest areas for improvement in order to make the tool more reliable.

Cronbach's apha was also calculated to confirm the reliability of the questionnaire. Cronbach's alpha is referred to as a measure of "internal consistency" reliability and it is one of the most widely used measures of reliability in the social and organizational sciences (Bonnet \& Wright, 2014). The cronbach's alpha in this study's questionnaire was found to be 0.808 . A general accepted rule is that $\alpha$ of 0.6 0.7 indicates an acceptable level of reliability, and 0.8 or greater a very good level (Urasach, Horodinic \& Zait, 2015). This entails that the questionnaire used for the study was reliable.

B. Multiple Regression Assumptions: Linear regression is a classic, commonly used prediction tool. However, it requires data that satisfy certain conditions (assumptions), including normality, homoscedasticity, and multicollinearity that may not be met in complex data sets (Gelfand, 2015). Violation of any of these assumptions can result into biased estimates of relationships, over or under-confident estimates of the precision of regression coefficients (i.e., biased standard errors), and untrustworthy confidence intervals and significance tests (Chatterjee \& Hadi, 2012). Diagnostic tests of the three assumptions were done.

1. Multi Colinearity Assumption: Collinearity of predictor variables in a linear regression refers to a situation where explanatory variables are correlated with each other. The terms, multicollinearity and ill conditioning, are also used to denote the same situation (Liao \& Valliant, 2012). A good model is expected to have as little overlap between 
predictors as possible (Ernst, \& Albers, 2017). The results of collinearity statistics show that there was no problem of multicollinearity. As it can be seen from table I all tolerances and variance inflation factor (VIF) are significantly greater than 0.1 and smaller than 10 respectively. A commonly given rule of thumb is that VIFs of 10 or higher (or equivalently, tolerances of .10 or less) may be reason for concern.

TABLe I Multicolineality Diagnostic Results For THE Model USING COLINEARITY TESTS STATISTICS

\begin{tabular}{|l|c|c|}
\hline \multicolumn{3}{|c|}{ Co-linearity Statistics } \\
\hline Variable & Tolerance & VIF \\
\hline (Constant) & & \\
\hline Academic Performance & .998 & 1.002 \\
\hline Gender & .997 & 1.003 \\
\hline Entrepreneurship Education & .987 & 1.013 \\
\hline Self-employed Parents & .988 & 1.013 \\
\hline \multicolumn{2}{|c|}{ Dependent Variable: Self-employment Intentions }
\end{tabular}

2. Homoscedasticity Assumption: One assumption of multiple regression analysis is homoscedasticity of errors. Heteroscedasticity may result from misspecification due to overlooked nonlinear predictor terms or to unobserved predictors not included in the model (Klein, Gerhard, Büchner, Diestel \& Schermelleh-Engel, 2016). To detect homoscedasticity the study applied graphical method by observing residual plots in a scatter diagram produced by SPSS. According to Gelfand (2015) when the condition of homoscedasticity is satisfied, the residuals should be randomly and uniformly scattered around the horizontal line at 0 . When heteroscedasticity is present, particularly when the variance is proportional a power of the mean, there is a fan shape to the residuals. As it can be seen in figure 1 the residuals are randomly and uniformly scattered around the horizontal line at 0 and therefore the assumption of homoscedasticity was met.

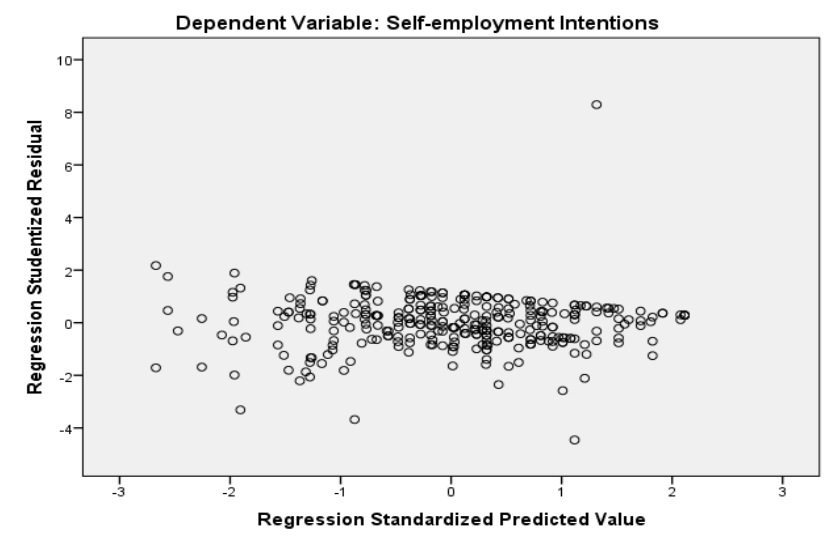

Fig. 2 Scatter Plot of Homoscedasticity Test

3. Normality Assumption: In statistics it is conventional to assume that the observations are normal. The entire statistical framework is grounded on this assumption and if this assumption is violated the inference breaks down. For this reason it is essential to check or test this assumption before any statistical analysis of data (Das \& Imon, 2016). Since fig. 2 shows that the points follow the diagonal line, it can be concluded that the residual value is normally distributed and therefore the normality assumption was met.

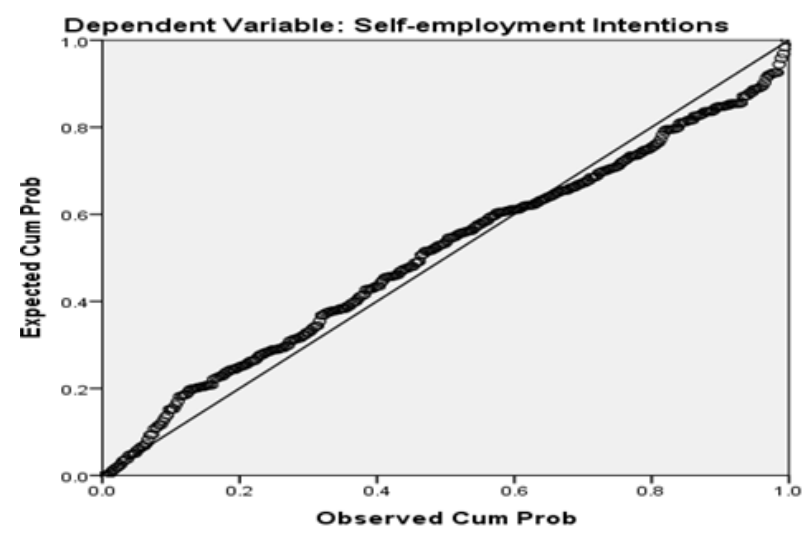

Fig. 3 Normal P-P Plot of Regression Standardized Residual

C. Demographic Characteristics of Respondents: The study involved 400 respondents. However, 344 returned the questionnaires from which 163 were males (47.4\%) were and 181 (52.6\%) were females. Out of all the respondents 280 (81.4\%) were undergraduate students and 64 (18.6\%) were master's degree students.

TABLE II RESPONDENTS’ CHARACTERISTICS

\begin{tabular}{|c|c|c|c|}
\hline Study level/Gender & Male & Female & Total \\
\hline Undergraduate Students & 130 & 150 & 280 \\
\hline Master's Students & 33 & 31 & 64 \\
\hline Total & 163 & 181 & 344 \\
\hline
\end{tabular}

D. Multiple Linear Model: Multiple linear regression analysis was used to test if four independent variables (academic performance, entrepreneurship education, selfemployed parents and gender) significantly predicted Selfemployment intentions. The multiple linear regression model was initially expressed as follows;

$\mathrm{SI}=\beta_{0}+\beta_{1} \mathrm{GEN}+\beta_{2} \mathrm{EDU}+\beta_{3} \mathrm{PER}+\beta_{4} \mathrm{PAR}+\varepsilon$

Where

SI=Self-employment intentions

$\beta_{0=}$ constant (coefficient of intercept)

GEN=Gender

EDU=Entrepreneurship Education

PER=Academic Performance

$\mathrm{PAR}=$ Self-employed parents

$\beta_{0}-\beta_{4}=$ Regression coefficient of five variables $\varepsilon=$ Error term

TABLE III MODEL SUMMARY

\begin{tabular}{|c|c|c|c|c|}
\hline Model & $\mathbf{R}$ & $\begin{array}{c}\mathbf{R} \\
\text { Square }\end{array}$ & $\begin{array}{c}\text { Adjusted R } \\
\text { Square }\end{array}$ & $\begin{array}{c}\text { Std. Error of } \\
\text { the Estimate }\end{array}$ \\
\hline 1 & $.363^{\mathrm{a}}$ & .132 & .121 & .78483 \\
\hline
\end{tabular}

a. Predictors: (Constant), Self-employed Parents, Academic Performance, Gender, Entrepreneurship Education 
Table III shows the model summary. Correlation coefficient value, $r=0.363$ shows that the four independent variables together are relatively good predictor of self-employment intentions. Moreover, $\mathrm{r}^{2}=.132$ suggests that $13.2 \%$ variation in self-employment intentions is explained by the four independent variables included in the model. This means $86.8 \%$ of the variation is explained by other factors that were not included in the model. Selection of independent variables included in the model may be one of the reasons why variation of the dependent variable is largely explained by other factors rather than the four variables included in the model which are gender, academic performance, entrepreneurship education and self-employed parents.

The goodness of fit test in table IV shows that the model was a good predictor of self-employment intentions among the students, $F(4,319)=12.14, p=.000$

TABLE IV ANOVA

\begin{tabular}{|l|c|c|c|c|c|}
\hline \multicolumn{1}{|c|}{ Model } & Sum of Squares & df & Mean Square & F & Sig. \\
\hline Regression & 29.899 & 4 & 7.475 & 12.135 & $.000^{\text {b }}$ \\
\hline Residual & 196.488 & 319 & .616 & & \\
\hline Total & 226.388 & 323 & & & \\
\hline \multicolumn{6}{|c|}{ a. Dependent Variable: Self-employment Intentions } \\
\hline \multicolumn{2}{|c|}{ b. Predictors: (Constant), Self-employed Parents, Academic Performance, Gender, Entrepreneurship Education } \\
\hline
\end{tabular}

TABLE V ESTIMATED COEFFICIENTS

\begin{tabular}{|c|c|c|c|c|c|}
\hline Model & & $\begin{array}{l}\text { Unstandardized } \\
\text { Coefficients }\end{array}$ & $\begin{array}{c}\text { Standardized } \\
\text { Coefficients }\end{array}$ & $\mathrm{t}$ & Sig. \\
\hline & B & Std. Error & Beta & & \\
\hline (Constant) & 3.003 & .192 & & 15.670 & .000 \\
\hline Academic Performance & .016 & .039 & .022 & .425 & 671 \\
\hline Gender & -.028 & .087 & -.017 & -.318 & .751 \\
\hline Entrepreneurship Education & .303 & .048 & .333 & 6.341 & .000 \\
\hline Self-employed Parents & .211 & .097 & .114 & 2.172 & .031 \\
\hline
\end{tabular}

a. Dependent Variable: Self-employment Intentions

Results from table 5 shows that entrepreneurship education found to have influence on self-employment intentions $(\beta=.303, p=.000)$ and therefore it has a positive significant association with self-employment intentions. Since $p=.000$ at $\alpha=0.05$ we failed to reject the null hypothesis and therefore conclude that entrepreneurship education has significant association with students' self-employment intentions. The findings imply that students who are more informed and educated on entrepreneurship are more likely to have entrepreneurship intentions than those who are less educated or not educated at all on entrepreneurship. The findings are supported by Hattab (2014); Tarus, Kemboi, Okemwa and Otiso (2016); and Nyello, Kalufya, Rengua, Nsolezi and Ngirwa (2015).

The study also found that having self-employed parent(s) have a significant association with self-employment intentions $(\beta=.211, \mathrm{p}<.05)$ and therefore it has as significant association with self-employment intentions. Since $p=.031$ at $\alpha=0.05$ we have sufficient evidence to reject the null hypothesis and therefore conclude that having at least one parent who is self-employed has a significant association with students' self-employment intentions. The literature argues that children tend to consider their parents as role models and therefore if parents are self-employed children are also more likely to have intentions to become selfemployed in the future (Megibaru, 2014 ; Fatoki, 2014;
Kumar and Prabhu, 2017 ). However, the study of Rachmawan, Lizar and Mangundjaya (2015) found inconsistent results which contradict even what this study found.

Results from regression indicated that gender is insignificant $(\mathrm{p}=.751)$ and therefore it has no any influence on self-employment intentions. Since $p=.751$ at $\alpha=0.05$ we have sufficient evidence to accept the null hypothesis and therefore conclude that gender of students have no significant association with their self-employment intentions. The findings imply that whether a student is a male or a female it has nothing to do with his or her selfemployment intentions. The study's findings are consistent with those of Indarti and Kristiansen (2003); Nguyen (2018); and Ojeyumi, Oyekele, Agberotimi, and Odedayo (2018) among many others that found no significant statistical relationship between gender and self-employment intentions. Contrary to the findings the study of Jinying and Pelagie (2014) found an association between gender and Self-employment intentions.

From table V regression analysis results show that academic performance is insignificant $(\mathrm{p}=.671)$ and therefore it has no any influence on self-employment intentions. Therefore, we have sufficient evidence to accept the null hypothesis and conclude that academic performance of students have no 
significant association with their self-employment intentions. This implies that whether a student has a pass (2.0 - 2.6 GPA), lower second (2.7 - 3.4GPA), upper second (3.5 - 4.3GPA) or first class (4.4 - 5.0 GPA) his/her academic performance has no any association with selfemployment intentions. This finding are similar to those of Acharja (2017) and Osakede, Lawanson and Sobowale (2017) which concluded that academic performance of students has no significant relationship with selfemployment intentions. However, study of Bhassegem (2016) showed a weak relationship $\left(\mathrm{R}^{2}=0.042\right)$ between academic performance and self-employment intentions.

\section{CONCLUSION AND RECOMMENDATIONS}

The study concludes that entrepreneurship education and having at least one parent who is self-employed have significant association with self-employment intentions of students in Tanzania higher learning institutions while academic performance and gender of students have no significant association with self-employment intentions. This entails that university curriculums should be designed in such a way that facilitate students in higher learning institutions to have sufficient entrepreneurship knowledge and skills. This also reminds students in higher learning institutions to have personal initiatives in looking for entrepreneurship education from formal and informal channels such as internet, reading books, etc. In acknowledging the fact that unemployment has been one of major problems in our societies, parents should consider having businesses as their major or alternative sources of income in order to influence their children to have entrepreneurial tendencies.

\section{REFERENCES}

[1] Ahmed, I., Nawaz, M.M, Ahmad, Z., Shaukat, M. Z., \& Usman, A. (2010). Determinants of Students' Entrepreneurial Career Intentions: Evidence from Business Graduates. European Journal of Social Sciences, 15(2), 14-22.

[2] Al-Harrasi, A. S, Al-Zadjali, E., \& Al-Salti, Z .S. (2014). Factors Impacting Entrepreneurial Intention: A Literature Review. International Journal of Social, Management, Economics and Business Engineering, 8(8), 2438-2441.

[3] Acharja, I. L (2017). Effect of individual factors on entrepreneurial intentions among undergraduate students in Bhuttan. World Journal of Business and Management, 3(2), 1-12.

[4] Asadollahi, T., Miri, M. R., Norozi, E., Hosseini, T., \& Sharifzade, G. (2017). An Enquiry into the Predictive Power of the Theory of Planned Behavior for Attachment Styles of Housewives. Health Education and Health Promotion, 5(1), 19-29.

[5] Bhassegem, C. (2016). The mediating effect of entrepreneurial selfefficacy on the relationship between academic grade and entrepreneurial intention. Master's thesis, Louvan School of Management

[6] Bonnet, D. G. \& Wright, T. A. (2014). Cronbach's alpha reliability: Interval estimation, hypothesis testing, and sample size planning. Journal of Organizational Behavior, 5(2), 23-43.

[7] Burchell, B.J. \& Coutts, A, P. (2018). The Experience of SelfEmployment Among Young People: An Exploratory Analysis of 28 Low- to Middle-Income Countries. Sage Publications, 63(2), 147-165

[8] Cadar, O. \& Badulescu, D. (2015). Entrepreneur, Entrepreneurship and Intrapreneurship. A Literature Review. Munich Personal RePEc Archive Paper Series, Paper No. 78871.
[9] Chatterjee \& Hadi (2006). Regression Analysis by Example. (4 ${ }^{\text {th }}$ Ed.) Hoboken, USA: John Wiley \& Sons.

[10] Conelly, L. M. (2008). Pilot Studies. Medsurg Nursing, 17(6), 411-2.

[11] Das, K. R., \& Imon, A. H. (2016). A Brief Review of Tests for Normality. American Journal of Theoretical and Applied Statistics. 5(1), 5-12.

[12] Ernst, A. F., \& Albers, C. J. (2017). Regression assumptions in clinical psychology research practice - a systematic review of common misconceptions. PeerJ, 5(2), 2-16.

[13] Faloye, D. O., \& Olatunji, O. D. (2018). Entrepreneurship Education and Self-employment Intentions among Fresh Graduates in Nigeria. Journal of Economics and Sustainable Development, 9(12), 146-158.

[14] Farrukh, M., Alzubi, Y. Shahzad, I.A. \& Kanwal, N. (2018). Selfemployment intentions: The role of personality traits in perspective of theory of planned behaviour". Asia Pacific Journal of Innovation and Entrepreneurship, 12(3), 399-414. Retrieved from: https://doi.org/10.1108/APJIE-01-2018-0004

[15] Fatoki, O. (2014). Parental and Gender Effects on the Entrepreneurial Intention of University Students in South Africa. Mediterranean Journal of Social Sciences, 5(7), 155-162.

[16] Gelfand, S. J. (2015). Understanding the Impact of Heteroscedasticity on the Predictive Ability of Modern Regression Methods. Dissertation Submitted in Partial Fulfillment of the Requirements for the Degree of Master of Science in the Department of Statistical and Actuarial Science Faculty of Science.

[17] Ghose, A.K, Majid, N. \& Ernst, C. (2008). The global employment challenge. Geneva: ILO

[18] Greco, A. \& Jong, G. (2017). Sustainable entrepreneurship: definitions, themes, and research gaps. Working paper series. University of Groningen.

[19] Hattab, (2014). Impact of Entrepreneurship Education on Entrepreneurial Intentions of University Students in Egypt. The Journal of Entrepreneurship, 23(1), 1-18.

[20] Havinal, V. (2009). Management and Entrepreneurship. New Delhi, India: New Age International (P) Limited.

[21] Hessels, J., \& Naude, W. (2017). The Intersection of the Fields of Entrepreneurship and Development Economics: A Review towards a New View. Discussion paper series, Paper No.11103, IZA Institute of Labour Economics, Bonn, Germany.

[22] Hwang, Y. (2017). What Is the Cause of Graduates' Unemployment? Focus on Individual Concerns and Perspectives. Journal of Educational Issues, 3(2), 1-10. Retrieved from: http://dx.doi.org/ 10.5296/jei.v3i2.11378.

[23] ILO (2018). Labour Market Profile: Tanzania \& Zanzibar. Danish Trade Union Council for International Development Cooperation, Ulandssekretariatet, Denmark.

[24] Indarti, N. \& Kristiansen, S. (2003). Determinants of entrepreneurial intention: The Case of Norwegian Students, Gadjah Mada International Journal of Busines, 5(1), 79-95.

[25] Isral, M. \& Saleem, M. (2018). Entrepreneurial intentions among university students in Italy. Journal of Global Entrepreneurship Research, 8(20), 234-246. Retrieved from: https://doi.org/10.1186/ s40497-018-0107-5.

[26] Jinying, W. \& Pelagie, P. P. (2014). Determinants of Entrepreneurial Intention among African Students in China. International Journal of Higher Education, 3(4), 106-119.

[27] Katundu, M. A. \& Gabagambi, D. M. (2014). Entrepreneurial Tendencies of Tanzanian University Graduates: Evidence from University of Dar-es-Salaam. European Journal of Research, 1(12), 5525-5558.

[28] Klein, A. G., Gerhard, C., Büchner, R., Diestel, S. \& SchermellehEngel, K. (2016). The detection of heteroscedasticity in regression models for psychological data. Psychological Test and Assessment Modeling, 58(4), 567-592.

[29] Kothari, C. (2011). Research Methodology; Methods and Techniques. New Delhi, India : New Age International Publishers

[30] Kumar, R. (2011). Research Methodology: A Step-by-Step Guide for Beginners. (3rd Ed.). New Delhi, India: Sage Publishers

[31] Kumar, S. A. \& Prabhu, J. J. (2017). Understanding Parental Factors and Entrepreneurial Attitude - The Moderating Effect of Entrepreneurship. International Journal of Advance Research and Innovative Ideas in Education, 3(6), 1371-1374. 
[32] Leavell, J. P. (2017). Controlling and Informational Planned Behavior: Self-Determination Theory and the Theory of Planned Behavior. Atlantic Marketing Journal, 5(3) , 81-91

[33] Liao, D. \& Valliant, R. (2012). Variance inflation factors in the analysis of complex survey data. Survey Methodology, 38(1), 53-62.

[34] Megibaru, S. (2014). Socio-Demographic Determinants for Entrepreneurial Intention of University Students: The Case of University of Gondar Graduating Students. Eurasian Journal of Business and Economics. 4(1), 51-82. Retrieved from: http://dx.doi.org/10.4314/ejbe.v4i1.2

[35] Mugenda, O. M., \& Mugenda, A. G. (2012). Research Methods: Quantitative and Qualitative Approaches. Nairobi, Kenya : Acts Press.

[36] Johnmark, D. R., \& Munene, J. (2016). Discrimination in Predicting Entrepreneurial Intentions of the Disabled Students in Nigeria. International Journal of Managerial Studies and Research, 4(1), 113. Retrieved from: https://doi.org/10.20431/2349-0349.040100

[37] Mwasalwiba, E., Dahles, H., Wakkee, I. (2012). Graduate Entrepreneurship in Tanzania: Contextual Enablers and Hindrances. European Journal of Scientific Research, 76(3), 386-402.

[38] Mwiya, B., Wang, Y., Kaulung'ombe, B., \& Kayekesi, M. (2018). Exploring Self-employment intention's Mediating Role in the Relationship between Self-Efficacy and Nascent Behaviour: Evidence from Zambia, Africa. Journal of Small Business and Enterprise Development, 12(3), 67-78.

[39] Neuman, W. (2014). Social Research Methods: Qualitative and Quantitative Approaches. Essex, UK: Pearson.

[40] Nguyen, C. (2018). Demographic factors, family background and prior self-employment on entrepreneurial intention - Vietnamese business students are different: why? Journal of Global Entrepreneurship Research, 8(10), 2-1. Retrieved from: https://doi. org/10.1186/s40497-018-0097-3.

[41] Nyello, R., Kalufya,N., Rengua, C., Nsolezi, M. J \& Ngirwa, C. (2015). Effect of Entrepreneurship Education on the Entrepreneurial Behaviour: The Case of Graduates in the Higher Learning Institutions in Tanzania, Asian Journal of Business Management, 7(2), 37-42.

[42] Ojewumi, A.K., Agberotimi, Adedayo, O. (2018). Obafemi Awolowo University Undergraduate Students: The Influence of Gender and Self-Efficacy on Entrepreneurial Intentions. The Journal of Pan African Studies, 11(2), 168-185.

[43] Osakede, U. A., Lawanson, A. O., \& Sobowale, D. A. (2017). Entrepreneurial interest and academic performance in Nigeria: evidence from undergraduate students in the University of Ibadan. Journal of Innovation and Entrepreneurship, 6(19). Retrieved from: https://doi.org/10. 1186/s13731-017-0079-7

[44] Popoola, O. \& Ajayi, O. (2016). National Directorate of Employment (NDE) and Rural Empowerment in Oyo State, Nigeria. International Journal of Business and Social Science, 7(8), 164-170.

[45] Poschke, M. (2018). Wage employment, unemployment and selfemployment across countries. International Growth Center, Working paper, F-32205-ETH-1.

[46] Rachmawan, A., Lizar, A. A., Mangundjaya, W. (2015). The role of parent's influence and self-efficacy on entrepreneurial intention. The journal of developing areas, 49(3), 418-430.

[47] Silva, A. \& Nobre, N. (2018). Students' Entrepreneurial Propensity: An Exploratory Study from a Portuguese Polytechnic School. Journal of Entrepreneurship and Organization Management, 7(1), 1-6.

[48] Tarus, T. K, Kemboi, A., \& Okemwa, D. O., \& Otiso, K. N. (2016).Determinants of Entrepreneurial Intention: Selected Kenyan Universities Service Sector Perspective. International Journal of Small Business and Entrepreneurship Research, 4(6), 41-52.

[49] The Citizen (2017). Life after University: What's next for the New Graduates? Retrieved from: https://www.thecitizen.co.tz/ magazine/ success/Life-after-university--What-s-next-for-the-new-graduates/1843788-4225020-woebqnz/index.html accessed on 20th April, 2019

[50] Thompson, E. R. (2009). Individual Self-employment intent: Construct clarification and development of an internationally reliable metric. Entrepreneurship Theory and Practice, 33(3), 669-694

[51] Torres, F. C, M'endez, J. C., Barreto, K. S, Chavarr'ia , A. P., Machuca, K. J., \& Guerrero, J . A. (2017). Exploring entrepreneurial intentions in Latin American university students. International Journal of Psychological Research, 10(2), 46-59.

[52] Urasachi, G., Horodnic, I.A., \& Zait, A. (2015). How reliable are measurement scales? External factors with indirect influence on reliability estimators, Procedia Economics and Finance, 12(20), 679 $-686$.

[53] Williams, H., He, W., \& Conners, S. (2018). Stakeholder Loyalty in Mergers: An Application of Theory of Planned Behavior. Journal of Academic Administration in Higher Education, 14(1), 37-44

[54] Zainal, Z. (2007). Case study as a research method. Jurnal Kemunisiaan, 5(1), 1-6.

[55] Zhang, K. (2018). Theory of Planned Behavior: Origins, Development and Future Direction. International Journal of Humanities and Social Science Invention, 7(5), 76-83. 